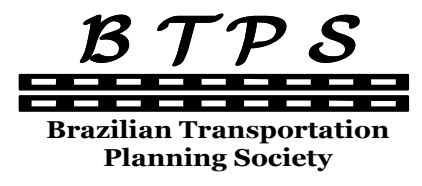

\author{
Journal of Transport Literature \\ Vol. 8, n. 2, pp. 100-112, Apr. 2014 \\ Research Directory
}

JTL | RELIT

www.transport-literature.org ISSN 2238-1031

\title{
Risk perception factors and their influence on road transportation
}

[Fatores de percepção de risco e sua influência sobre o transporte rodoviário]

\author{
Aderinlewo Olufikayo*, Ata Grace \\ Federal University of Technology Akure - Nigeria, Federal University of Technology Akure - Nigeria
}

Submitted 5 Apr 2013; received in revised form 20 Jun 2013; accepted 22 Jun 2013

\begin{abstract}
This study assesses risk in road transportation in Ekiti State, Nigeria through a number of factors as well as the various ways by which these factors are perceived through Pearson correlation analysis. Six roads were identified as case studies from which information about how the users perceived risk was obtained mainly by administering questionnaires. The responses to the 23 questions which were developed based on the risk factors were analyzed statistically to obtain their relationships in terms of their correlation coefficients and R-squared values. The most dominant risk factors with respect to the roads considered as case studies were identified and the relationships between them were determined. The results showed that the most correlated risk factors are "drinking and driving (DAD)", "using a mobile phone (hands free) and driving (UMP(hf)AD)", "taking medicine and driving (TMAD)" and "using a mobile phone (hands free) and driving (UMP(hf)AD)" with Pearson correlation coefficient of 0.9772 and R-squared value of 0.9549 .
\end{abstract}

Key words: risk, road transportation, risk factors, correlation coefficients, $R$-squared values.

\section{Resumo}

Este estudo avalia o risco no transporte rodoviário no Estado de Ekiti, Nigéria, por meio de uma série de fatores e das diversas maneiras pelas quais esses fatores são percebidos, utilizando uma análise de correlação de Pearson. Utilizou-se como estudo de caso um conjunto de seis estradas daquele estado, sendo extraídas informações sobre como os usuários percebem o risco de acidentes por meio de aplicação de questionários. As respostas às 23 perguntas desenvolvidas com base nos fatores de risco foram analisadas estatisticamente com vistas à obtenção de relações em termos de seus coeficientes de correlação e valores de $R$. quadrado. Identificou-se, assim, os fatores de risco mais dominantes e suas interrelações. Os resultados mostraram que os fatores de risco mais correlacionadas entre si são "beber e dirigir" e "usar telefone celular (mãos livres) e dirigir", bem como "tomar os medicamentos e dirigir" e "usar telefone celular (mãos livres) e dirigir", com coeficiente de correlação de Pearson de 0,9772 eo valor de R-quadrado de 0,9549.

Palavras-Chave: risco, transporte rodoviário, fatores de risco, coeficientes de correlação, valores de R-quadrado.

*Email: faderin2010@yahoo.com.

\section{Recommended Citation}

Olufikayo, A. and Grace, A. (2014) Risk perception factors and their influence on road transportation. Journal of Transport Literature, vol. 8, n. 2, pp. 100-112.

- JTL/RELIT is a fully electronic, peer-reviewed, open access, international journal focused on emerging transport markets and published by BPTS - Brazilian Transport Planning Society. Website www.transport-literature.org. ISSN 2238-1031.

This paper is downloadable at www.transport-literature.org/open-access. 


\section{Introduction}

The dominant mode of transportation in Nigeria is the roadway and it is also the mode that records the highest number of fatalities, injuries and number of crashes. An analysis of the traffic crash data recorded over a five year period between 2000-2006 shows that 98,494 cases of traffic crashes were recorded out of which 28,366 were fatal and resulted into 47,092 deaths (FRSC, 2009). The data shows Nigeria is fore front of all nations (especially the third world nations) experiencing the highest rate of road tragedies in the world.

The fundamental objective of any intervention or countermeasure in transportation is to reduce the chances of occurrence and consequences of risk in road transportation. The main goal is to reduce casualties in any incident through the assessment of accident data/information and risk perception. The condition of roads can be described as a major factor contributing to the crashes on our roads. Although the attitude of road users can not be emphasized, the impact of road signs and road markings availability on drivers cannot be ignored. The need to investigate road accidents/ crashes in Ado-Ekiti has become necessary in order to create public awareness as regards Risk/accidents on state roads. Although lack of regular road maintenance such as the provision of traffic lights, line drains, median kerbs, side kerbs, bridges, and pavements/road side shoulders, roundabouts.

Other essential road furniture include guard rails, safety systems (emergency medical vehicle and shelter), towing vehicles, parking facilities, junctions/intersections, pedestrian facilities (bridge/walkway), bicyclist facilities, motorcycle/tricycle facilities, bus way/bus priority lanes, lay -byes, street lights, and road markings are missing in Ado-Ekiti State roads. Road signs, bus shelters/stops and speed bumps/humps are other road furniture adequately needed in order to ensure good and smooth running of the transportation system.

This study aims to assess the role of risk perception and other risk related judgement in road transportation with Ado-Ekiti as a case study. It also intends to identify and analyse the causes of road accidents in Ado-Ekiti, identify and assess risk indicators in road transportation and how they can be measured, establish a process by which risk can be handled by individuals as 
well as the transportation authorities concerned and assess risk perception with regard to road transportation by individuals and the relevant transportation authorities.

In this study, the most dominant risk factors with respect to the roads considered as case studies were identified and the relationships between them were determined. Previous studies showed that factors such as price of motor insurance, level of income and religious beliefs influenced risk perception of Nigerian motorists based on the measured Pearson correlation coefficients between them (Onafalujo et al, 2011). Other studies showed high correlation between the occurrence of risk/risk perception and risk factors such as overspeeding and abused health/substance abuse (Wang et al, 2011).

This section introduces the aim and objectives of the study, Section 1 provides a theoretical background of the study, Section 2 describes the methodology for collecting the data, Section 3 explains how the data was analysed as well as discusses the results obtained. The paper is rounded off with a comprehensive conclusion.

\section{Theoretical Background}

Risk assessment is defined as the scientific process of identifying unwanted consequences (and their causes) and calculating their probabilities and magnitude (Renn, 2000). Amplification of risks through lack of information or misinformation can contribute to the amplification of risk fears leading to 'infodemics' which may have equally serious impacts as the risks themselves (World Economic Forum, 2006). Some of the risks that affect road transportation include; impatience of drivers, impatience of road users, fatigue, vehicle bad condition, children playing on the road, over speeding, taking drugs and driving, poorly maintained road, poor health condition, climatic change, traffic congestion, drinking and driving, using a mobile phone(hand-held) while driving, using mobile phone (hands-free) while driving and over speeding.

Common causes of these accidents included speeding, drunk driving and careless driving. About $10 \%$ of those killed were inexperienced drivers. A "factor" is a circumstance contributing to a result. Without this factor, the result would not exist but the factor alone is an element that, by itself, cannot produce the result. The term "contributing factor" is 
meaningless if this definition is accepted. A factor must be contributing if it is present otherwise it is not a factor. The term "primary factor" is sometimes used by experts to indicate a factor that was strong in its contribution to the accident. This is misleading as there can be no one factor more important than any other if all factors must have been present to produce a result. No factor can be secondary, or less important than another if all are required for the result. Like the links of a chain, all must be present and none is more or less necessary than the other.

Conditions and events are closely interrelated when considering accident factors. Some may be obvious and others difficult to determine. If a large truck is involved in an accident and the fuel tank is ruptured, the cause of the rupture and resulting fuel spill is readily determined. If the fuel was to ignite, the cause of the ignition may be indeterminate but subject to speculation.

There are three main factors responsible for road accidents namely human factors emanating from the road user/drivers and their characteristics, environmental factors which are related directly to the road way/weather characteristics and mechanical factors which are related to the vehicle characteristics. Road accidents are often a sequence of causes such as distracted driving, overspeeding, drunk driving, reckless driving/tailgating, vehicle defects, foggy weather, driving under the influence of drugs, tire blow-out among several others.

Strategies used to manage risks as well as the occurrence of accidents can be grouped according to the level of knowledge and uncertainty associated with a specific risk. Renn (2000) uses three categories to define the types of strategic approaches namely risk-based management, precaution-based management and discourse-based management. The first case is dependent on the scientific assessment of probabilities and is the classic example of risk management. The second case covers incidents where there is a high degree of uncertainty requiring methodologies such as more research, contained experimentation and ongoing monitoring to be employed. The third case applies when the potential for wide-ranging damage is ignored due to delayed effect of the risk (Klinke and Renn, 2002). Many risk regulatory frameworks work on this premise under the ALARP (As Low as Reasonably Practicable) principle where risks are reduced to as low level as possible within the contexts of balancing costs and benefits. 
Hence such risk needs to be communicated through exchange of information using various mechanisms, among interested parties about the aspects of risk. Risk communication aims to create trust and confidence in risk decision-making processes, ensure that experts and regulators discuss all relevant issues and engage stakeholders in a two-way communication process (DETR, 2000).

These assertions imply that even though societies appoint 'informed persons' to make determinations about risk on their behalf, the public need to be informed not just of the result but about the processes and the inputs used to arrive at the result, including their own contributions. The difficulties associated with communicating risk information effectively revolve around characteristics and limitations of science and perception fall into four categories namely scientific data about risk, spokespersons in communicating information about risks, the media in reporting information about risks and the public in evaluating and interpreting risk information (Vrouwenvelder et al, 2001).

Problems that compound the difficulties of communicating risk to the public include: lack of coordination among responsible bodies, different mandates and lack of clarity with respect to responsibility and authority, leading ultimately to decline in public trust. Public trust in official bodies is undermined if the communication process does not make the issues more understandable, is inconsistent in both quality and frequency, and is not responsive to the needs of the public (Vrouwenvelder et al, 2001).

Risk information is conveyed through a wide variety of channels. Peer reviewed journals provide detailed technical data and findings about scientific trials and new technologies to specialized audiences. The most pervasive forms of information dissemination however are the media and word of mouth. Several studies have identified the media, in all its forms, as an influential player in the shaping of people's perceptions of risks. There is no direct measurement of this effect but the evidence suggests that some kinds of coverage make an impact on public behaviour, policy makers sometimes respond to media stories as a reflection of public opinion and government priorities and spending patterns influence media agendas (Harrabin et al, 2003). 
The speed of vehicles have a direct relationship to the level of risk involved in road transportation where speed limit can be described as the pace of a moving vehicle at a given time frame, according to laid down traffic laws. It is a maximum legal speed a driver can travel on a road under ideal conditions. Speed limit differs in application, depending on the types of roads, vehicles and the environment.

Different vehicles are required by law to keep within specified speed limits. In Nigeria, the law imposes maximum speed limit of $100 \mathrm{~km} / \mathrm{h}$ for cars on any highways in Nigeria. Taxis and buses are expected to maintain $50 \mathrm{~km} / \mathrm{h}$ within built up areas like streets in towns, villages and cities. Vehicles like tankers and trailers are expected to maintain a maximum speed limit of $50 \mathrm{~km} / \mathrm{h}$ on the highways and $60 \mathrm{~km} / \mathrm{h}$ on express ways. Most of the time when the weather condition might be bad or the road is defective, it is important that one should regulate the speed at ones vehicle is moving through the speed monitor.

Speeding is a deliberate and calculated behavior where the driver knows the risk but ignores the danger. The faster the speed of a vehicle, the greater the risk of an accident. The forces experienced by the human body in a collision increase exponentially as the speed increases. Speed limits for different vehicles on different roads are indicated in Table 1.

Table 1 - Speed Limits for Different Vehicles on Different Roads (in $\mathbf{k m} / \mathbf{h}$ )

\begin{tabular}{|l|c|c|c|}
\hline TYPES OF VEHICLES & TOWN AND CITIES & HIGHWAYS & EXPRESSWAY \\
\hline Motorcycles & 50 & 50 & 60 \\
\hline Private cars & 50 & 80 & 100 \\
\hline Taxi and buses & 50 & 80 & 90 \\
\hline Tankers/trailers & 45 & 50 & 60 \\
\hline Tow vehicle (while towing) & 45 & 45 & 45 \\
\hline Tow vehicle (while not towing) & 50 & 60 & 70 \\
\hline
\end{tabular}




\section{Database}

The data sources considered for use in this study can be classified into two groups namely primary and secondary sources. The primary sources involved the use of questionnaires for gathering the required information of road accidents in Ado-Ekiti while the secondary sources involved direct personal interviews with road transport officials in the areas considered as case studies as well as extraction of information from existing literature and the internet.

The data gathering exercise was mainly made possible through the use of structured questionnaires specifically designed for the purpose. The questionnaires were made very concise since vehicles and motorcycle riders are almost always on the move (except when waiting in queue to take their turn in passenger picking). The questions were related to how often the respondents thought that each of the following factors listed in Table 2 could be responsible for accidents.

These same questionnaires were also used to obtain data on vehicle use in Ado-Ekiti metropolis. The issues of interest among users and users' perception of the causes of vehicle and motorcycle crashes and the corresponding road facilities were extensively studied. The survey question consisted of 23 items relating to each factor which were rated on an ordinal six-point scale where a value of 1 indicates "Never", 2 indicates "Rarely", 3 indicates "Sometimes", 4 indicates "Often", 5 indicates "Very often" and 6 indicates "Always".

In order to acquire the data, 180 questionnaires were administered (30 questionnaires for each location considered as case study) and were sampled among vehicle and motorcycle riders (both commercial and private), victims of motorcycle crashes, various related organizations such as the Federal Road Safety Commission (FRSC), Ministry of Transport (MOT), Association of Vehicle and Motorcycle Operators in Ado-Ekiti (ACOMORON) and Hospitals. The questionnaires were also applied at various motorcycle terminals in Ado-Ekiti (where one-on-one interviews also took place during off peak periods and peak periods at low density and high density traffics respectively) corresponding to six different locations in AdoEkiti namely Old garage, Basiri road, Odo-ado, Ilawe road, Ajilosun and Opopogbooro. 
Table 2 - Comprehensive Layout of the Questionnaire

\begin{tabular}{|c|c|c|c|c|c|c|c|}
\hline \multicolumn{8}{|c|}{ How often do you think each of the following factors is the cause of road accidents? } \\
\hline 1 & Driving when tired & 1 & 2 & 3 & 4 & 5 & 6 \\
\hline 2 & Drinking and driving & 1 & 2 & 3 & 4 & 5 & 6 \\
\hline 3 & Following the vehicle in front too closely & 1 & 2 & 3 & 4 & 5 & 6 \\
\hline 4 & Driving too fast & 1 & 2 & 3 & 4 & 5 & 6 \\
\hline 5 & Taking medicines and driving & 1 & 2 & 3 & 4 & 5 & 6 \\
\hline 6 & Taking drugs and driving & 1 & 2 & 3 & 4 & 5 & 6 \\
\hline 7 & Poorly maintained road & 1 & 2 & 3 & 4 & 5 & 6 \\
\hline 8 & Using a mobile phone (hand-held) and driving & 1 & 2 & 3 & 4 & 5 & 6 \\
\hline 9 & Using a mobile phone (hands-free) and driving & 1 & 2 & 3 & 4 & 5 & 6 \\
\hline 10 & Traffic congestion & 1 & 2 & 3 & 4 & 5 & 6 \\
\hline 11 & Bad weather conditions & 1 & 2 & 3 & 4 & 5 & 6 \\
\hline 12 & Poor brakes/brake failure & 1 & 2 & 3 & 4 & 5 & 6 \\
\hline 13 & Bald tyres & 1 & 2 & 3 & 4 & 5 & 6 \\
\hline 14 & Burst tyres & 1 & 2 & 3 & 4 & 5 & 6 \\
\hline 15 & Faulty light & 1 & 2 & 3 & 4 & 5 & 6 \\
\hline 16 & Defective steering & 1 & 2 & 3 & 4 & 5 & 6 \\
\hline 17 & Using of seat belt/Lack of seat belt & 1 & 2 & 3 & 4 & 5 & 6 \\
\hline 18 & Impatience of road users & 1 & 2 & 3 & 4 & 5 & 6 \\
\hline 19 & Children playing on the road & 1 & 2 & 3 & 4 & 5 & 6 \\
\hline 20 & Other mechanical failure & 1 & 2 & 3 & 4 & 5 & 6 \\
\hline 21 & Defective horns & 1 & 2 & 3 & 4 & 5 & 6 \\
\hline 22 & Wind shield (Poor visibility) & 1 & 2 & 3 & 4 & 5 & 6 \\
\hline 23 & Absence of rear view & 1 & 2 & 3 & 4 & 5 & 6 \\
\hline
\end{tabular}


The factors considered are driving when tired (DWT), drinking and driving (DAD), following the vehicle in front too closely (FVFC), driving too fast (DTF), taking medicines and driving (TMAD), taking drugs and driving (TDAD), poorly maintained road (PMR), using a mobile phone (hand-held) and driving (UMP(hh)AD), using a mobile phone (hand-free) and driving (UMP(hf)AD), traffic congestion (TC), bad weather condition (BWC), poor brakes/break failure (PBF), bald tyres (BaT), burst tyres (BuT), faulty lights (FL), defective steering (DS), using of seat belt/Lack of seat belt (UOSB/LOSB), impatience of road users (IORU), children playing on the road (CPOTR), other mechanical failure (OMF), defective horns (DH), wind shield (poor visibility) (WS(PV)) and the absence of rear view (AORV).

\section{Discussion of Results}

Table 3 summarizes the percentages of respondents to various factors that could cause road accidents in the six locations that were considered. Table 3 shows that the highest value of risk factor was $40 \%$ for "Following the vehicle in front too closely" along Opopogbooro road and 38\% for "Traffic Congestion" along Old garage while the lowest value was $0 \%$ for "Following the vehicle in front too closely" along Ajilosun road and also 0\% for "Taking drugs and driving" along Ajilosun road.

The factors recorded along the roads were then correlated to determine whether there was any relationship between what was occurring along each of the roads based on their correlation coefficients. In addition, the R-squared values were calculated to determine the influence of the factors on one another.

Table 4 shows the pairs of factors with the highest correlation coefficients and most significant R-squared values. Table 4 also shows that the highest correlation coefficient of 0.9772 and R-squared value of 0.9549 were obtained between two pairs of risk factors "Drinking and driving (DAD) \& Using a mobile phone (hands free) and driving (UMP(hf)AD)" and "Taking medicine and driving (TMAD) \& Using a mobile phone (hands free) and driving (UMP(hf)AD)". The table only shows correlated factors with R-squared values greater than 0.5 . 
Table 3 - Comprehensive percentages (\%) of Respondents to Questionnaires along the roads

\begin{tabular}{|c|c|c|c|c|c|c|c|}
\hline $\mathrm{SN}$ & $\begin{array}{ll}\text { Risk factors } & \text { Roads } \\
\end{array}$ & $\begin{array}{l}\text { Old } \\
\text { garage }\end{array}$ & $\begin{array}{l}\text { Basiri } \\
\text { road }\end{array}$ & Opopogbooro & Ajilosun & $\begin{array}{l}\text { Ilawe } \\
\text { road }\end{array}$ & $\begin{array}{l}\text { Odo- } \\
\text { ado }\end{array}$ \\
\hline 1 & Driving when tired & $23 \%$ & $12 \%$ & $23 \%$ & $18 \%$ & $18 \%$ & $6 \%$ \\
\hline 2 & Drinking and driving & $14 \%$ & $9 \%$ & $24 \%$ & $29 \%$ & $19 \%$ & $5 \%$ \\
\hline 3 & $\begin{array}{l}\text { Following the vehicle in } \\
\text { front too closely (tailgating) }\end{array}$ & $27 \%$ & $13 \%$ & $40 \%$ & $0 \%$ & $13 \%$ & $7 \%$ \\
\hline 4 & $\begin{array}{l}\text { Driving too } \\
\text { fast[overspeeding] }\end{array}$ & $20 \%$ & $16 \%$ & $16 \%$ & $24 \%$, & $8 \%$ & $16 \%$ \\
\hline 5 & $\begin{array}{lll}\text { Taking medicines } & \text { and } \\
\text { driving }\end{array}$ & $14 \%$ & $9 \%$ & $24 \%$ & $29 \%$ & $19 \%$ & $5 \%$ \\
\hline 6 & Taking drugs and driving & $12 \%$ & $23 \%$ & $24 \%$ & $29 \%$ & $0 \%$ & $12 \%$ \\
\hline 7 & Poorly maintained road & $16 \%$ & $15 \%$ & $19 \%$ & $23 \%$ & $19 \%$ & $8 \%$ \\
\hline 8 & $\begin{array}{l}\text { Using a mobile phone } \\
\text { (hand-held) and driving }\end{array}$ & $25 \%$ & $16 \%$ & $21 \%$ & $17 \%$ & $17 \%$ & $4 \%$ \\
\hline 9 & $\begin{array}{l}\text { Using a mobile phone } \\
\text { (hands-free) and driving }\end{array}$ & $17 \%$ & $11 \%$ & $22 \%$ & $28 \%$ & $17 \%$ & $5 \%$ \\
\hline 10 & Traffic congestion & $38 \%$ & $23 \%$ & $8 \%$ & $15 \%$ & $8 \%$ & $8 \%$ \\
\hline 11 & Bad weather conditions & $12 \%$ & $12 \%$ & $12 \%$ & $29 \%$ & $17 \%$ & $18 \%$ \\
\hline 12 & Poor brakes/brake failure & $13 \%$ & $9 \%$ & $17 \%$ & $26 \%$, & $22 \%$ & $13 \%$ \\
\hline 13 & Bald tyres & $12 \%$ & $8 \%$ & $21 \%$ & $25 \%$ & $21 \%$ & $13 \%$ \\
\hline 14 & Burst tyres & $20 \%$ & $7 \%$ & $16 \%$ & $19 \%$ & $19 \%$ & $19 \%$ \\
\hline 15 & Faulty light & $5 \%$ & $11 \%$ & $17 \%$ & $17 \%$ & $22 \%$ & $28 \%$ \\
\hline 16 & Defective steering & $15 \%$ & $10 \%$ & $20 \%$ & $15 \%$ & $20 \%$ & $20 \%$ \\
\hline 17 & $\begin{array}{l}\text { Using of seat belt/Lack of } \\
\text { seat belt }\end{array}$ & $18 \%$ & $12 \%$ & $12 \%$ & $23 \%$ & $12 \%$ & $23 \%$ \\
\hline 18 & Impatience of road users & $17 \%$ & $12 \%$ & $23 \%$ & $18 \%$ & $12 \%$ & $18 \%$ \\
\hline 19 & $\begin{array}{l}\text { Children playing on the } \\
\text { road }\end{array}$ & $28 \%$ & $16 \%$ & $11 \%$ & $17 \%$ & $17 \%$ & $11 \%$ \\
\hline 20 & Other mechanical failure & $27 \%$ & $14 \%$ & $18 \%$ & $5 \%$ & $18 \%$ & $14 \%$ \\
\hline 21 & Defective horns & $12 \%$ & $17 \%$ & $18 \%$ & $12 \%$ & $12 \%$ & $29 \%$ \\
\hline 22 & $\begin{array}{l}\text { Wind shield (Poor } \\
\text { visibility) }\end{array}$ & $19 \%$ & $14 \%$ & $14 \%$ & $10 \%$ & $14 \%$ & $29 \%$ \\
\hline 23 & Absence of rear view & $12 \%$ & $19 \%$ & $19 \%$ & $12 \%$ & $13 \%$ & $25 \%$ \\
\hline
\end{tabular}




\section{Table 4 - Risk Factors with Highest Correlation Coefficients and most Significant R- squared Values}

\begin{tabular}{|c|c|c|c|c|}
\hline $\mathbf{S} / \mathbf{N}$ & \multicolumn{2}{|c|}{ Risk factors } & Correlation & \\
\hline 1 & $\begin{array}{l}\text { Drinking and driving } \\
\text { (DAD) }\end{array}$ & $\begin{array}{l}\text { Using a mobile phone (hands } \\
\text { free) and driving (UMP(hf)AD) }\end{array}$ & 0.9772 & 0.9549 \\
\hline 2 & $\begin{array}{l}\text { Taking medicine and } \\
\text { driving (TMAD) }\end{array}$ & $\begin{array}{l}\text { Using a mobile phone (hands } \\
\text { free) and driving (UMP(hf)AD) }\end{array}$ & 0.9772 & 0.9549 \\
\hline 3 & Defective horns (DH) & Absence of rear view (AORV) & 0.9641 & 0.9295 \\
\hline 4 & $\begin{array}{l}\text { Poor brakes/brake failure } \\
\text { (PBF) }\end{array}$ & Bald tires $(\mathrm{BaT})$ & 0.9529 & 0.9080 \\
\hline 5 & $\begin{array}{l}\text { Poorly maintained road } \\
\text { (PMR) }\end{array}$ & $\begin{array}{l}\text { Using a mobile phone (hands } \\
\text { free) and driving (UMP(hf)AD) }\end{array}$ & 0.9523 & 0.9069 \\
\hline 6 & Driving when tired (DWT) & $\begin{array}{l}\text { Using a mobile phone (hand } \\
\text { held) and driving (UMP(hh)AD }\end{array}$ & 0.9379 & 0.8797 \\
\hline 7 & $\begin{array}{l}\text { Drinking and driving } \\
\text { (DAD) }\end{array}$ & Poorly maintained road (PMR) & 0.9357 & 0.8755 \\
\hline 8 & Traffic Congestion (TC) & $\begin{array}{l}\text { Children playing on the road } \\
\text { (CPOTR) }\end{array}$ & 0.8887 & 0.7898 \\
\hline 9 & $\begin{array}{l}\text { Drinking and driving } \\
\text { (DAD) }\end{array}$ & Bald tires $(\mathrm{BaT})$ & 0.8886 & 0.7896 \\
\hline 10 & $\begin{array}{l}\text { Taking medicine and } \\
\text { driving (TMAD) }\end{array}$ & Bald tires (BaT) & 0.8886 & 0.7896 \\
\hline 11 & $\begin{array}{l}\text { Drinking and driving } \\
\text { (DAD) }\end{array}$ & Poor brakes/ brake failure (PBF) & 0.8366 & 0.6999 \\
\hline 12 & $\begin{array}{l}\text { Taking medicine and } \\
\text { driving (TMAD) }\end{array}$ & Poor brakes/ brake failure (PBF) & 0.8366 & 0.6999 \\
\hline 13 & Defective horns (DH) & Wind shield (Poor visibility) & 0.8148 & 0.6639 \\
\hline 14 & $\begin{array}{l}\text { Using a mobile phone } \\
\text { (hand held) and driving } \\
\text { (UMP(hh)AD }\end{array}$ & Poor brakes/ brake failure (PBF) & 0.7872 & 0.6198 \\
\hline 15 & Traffic Congestion (TC) & Bad weather condition (BWC) & 0.7773 & 0.6041 \\
\hline 16 & $\begin{array}{l}\text { Using a mobile phone } \\
\text { (hand held) and driving } \\
\text { (UMP(hh)AD }\end{array}$ & Bad weather condition (BWC) & 0.7593 & 0.5766 \\
\hline 17 & $\begin{array}{l}\text { Taking medicine and } \\
\text { driving (TMAD) }\end{array}$ & $\begin{array}{l}\text { Following the vehicle in front } \\
\text { too closely/tailgating (FVFC) }\end{array}$ & 0.7534 & 0.5676 \\
\hline 18 & $\begin{array}{l}\text { Taking drugs and driving } \\
\text { (TDAD) }\end{array}$ & Bad weather condition (BWC) & 0.7395 & 0.5469 \\
\hline 19 & $\begin{array}{l}\text { Taking drugs and driving } \\
\text { (TDAD) }\end{array}$ & Poor brakes/ brake failure (PBF) & 0.7297 & 0.5324 \\
\hline
\end{tabular}




\section{Conclusion}

Based on the results of this study, it can be inferred that "drinking and driving (DAD)", "taking medicine and driving (TMAD)" and "using a mobile phone (hands free) and driving (UMP(hf)AD)" are the most correlated risk factors for all the roads considered. Other risk factors with a high level of correlation include "defective horns (DH)", "absence of rear view (AORV)", "bald tires (BaT)", "poorly maintained road (PMR)", "driving when tired (DWT)", "using a mobile phone (hands free) and driving (UMP(hf)AD)", "using a mobile phone (hand held) and driving (UMP(hh)AD", "drinking and driving (DAD)" and "poor brakes/brake failure (PBF)". Priority should be given to these factors so as to reduce the occurrence of accidents on these roads since these are the main causative factors.

The major contribution of this study is that it has been able to develop a procedure for identifying the most dominant risk factors affecting road travel. It has also been able to assess the role of risk perception and other risk related judgement in road transportation with Ado Ekiti as a case study. A method for relating the risk factors has been developed through Pearson correlation analysis as well as through a measure of their R squared values. 


\section{References}

Carthy, T., Packham, D., Rhodes-Defty, N., Salter, D. and Silcock, D. (1993) Risk and safety on roads: perceptions and attitudes. Foundation for Road Safety Research, University of Newcastle Upontyne, pp. 51-54.

DETR (2000) Tomorrow's roads - safer for everyone. Department of the Environment, Transport and the Regions, London.

FRSC (2009) Road traffic crashes data. Federal Road Safety Commission www.frsc.gov.ng/rtc.php. Accessed on 31/03/2012.

Harrabin, R., Coote, A. and Allen, J. (2003) Health in the news - risk, reporting and media influence. Kings Fund, London.

Klinke, A. and Renn, O. (2002) A new approach to risk evaluation and management: risk-based, precaution-based and discourse-based strategies. Risk Analysis, vol. 22, no. 6, pp. 1071-1094.

Onafalujo, A., Abass, O. and Dansu, S. (2011) Effects of risk perception on the demand for insurance: implications on Nigerian road users. Journal of Emerging Trends in Economics and Management Sciences, vol. 2, no. 4, pp. 285-290.

Renn, O. (2000) Risks and society. Paper presented at the International Conference on Risk Analysis and its role in the European Union, Brussels.

Vrouwenvelder, T., Lovegrove, R., Holicky, M., Tanner, P. and Canisius, G. (2001) Risk assessment and risk communication in civil engineering. Safety, Risk, Reliability- Trends in Engineering, Malta.

Wang, P., Rau, P. and Salvendy, G. (2011) Chinese drivers' risky driving and risk taking in other life situations. International Journal of Occupational Safety and Ergonomics, vol. 17, no. 2, pp. 155-164

WEF (2012) New models for addressing supply chain and transport risk. World Economic Forum, Switzerland. 